\title{
A survey of calf management practices and farmer perceptions of calf housing in UK dairy herds
}

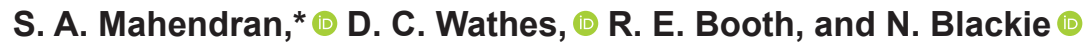 \\ Royal Veterinary College, Department of Pathobiology and Population Sciences, Hawkshead Lane, Hatfield, Hertfordshire AL9 7TA, \\ United Kingdom
}

\begin{abstract}
Adoption of optimal management techniques for rearing dairy calves has significant effects on their health, welfare, and productivity. Despite much published literature on best practice, calf morbidity and mortality rates remain high. This survey aimed to establish current calf management practices in the United Kingdom, along with farmer perceptions surrounding different housing types. A survey containing 48 questions was distributed online to UK farmers via social media, online forums, and a convenience sample of veterinary practices and was completed by 216 participants. A descriptive analysis with frequency distributions was calculated, with chi-squared tests, linear regression and multinomial regression performed to assess associations between variables. There was a low level of regular veterinary involvement in day-to-day health decision making for calves $(3 / 216,1.4 \%)$, highlighting the need for appropriate staff training and standard operating procedures to ensure prudent antimicrobial usage. Restricted calf milk feeding remains highly prevalent in the United Kingdom, with most calves fed milk replacer $(114 / 216,52.8 \%)$, twice daily $(189 / 216,87.5 \%)$, initially given milk at $4 \mathrm{~L} / \mathrm{d}(66 / 216,30.6 \%)$ or $6 \mathrm{~L} / \mathrm{d}$ $(47 / 216,21.8 \%)$. There was, however, a small number of farmers initially feeding only 2 to $3 \mathrm{~L} / \mathrm{d}(28 / 216$, $13.0 \%)$. Euthanasia of bull calves $(5 / 216,2.3 \%)$ and feeding antimicrobial waste milk to calves $(8 / 216,3.7 \%)$ both occurred on some farms. With regard to housing, use of individual calf pens has reduced from around $60 \%$ in 2010 to $38.4 \%$ in this study $(83 / 216)$, with this reduction being partly driven by the policy of UK milk buyers. Farmer perceptions indicated that individual housing was thought to help to improve calf health and feed monitoring of calves, suggesting that successful use of group housing requires a higher level of stockmanship. The majority of farmers did not provide fresh
\end{abstract}

Received April 21, 2021

Accepted September 15, 2021.

*Corresponding author: smahendran@rvc.ac.uk bedding to calves on a daily basis (141/216, 65.3\%), and relatively few disinfected both the calf housing $(38.0 \%)$ and ground $(47.7 \%)$ between calves, suggesting that hygiene practices may require additional attention in farm management protocols.

Key words: calf management, calf housing, dairy farming, survey, United Kingdom

\section{INTRODUCTION}

Efficient rearing of healthy dairy heifer replacement calves requires adoption of optimal management practices that are applied using consistent methods across all staff members. There has been a plethora of recent literature that has led to a greater understanding of optimal management practices for calf rearing (Sinnott et al., 2021; Bučková et al., 2021; Ghaffari and Kertz, 2021; Santman-Berends et al., 2021), but the successful communication of these findings to key stakeholders (Jansen et al., 2010b; Moya et al., 2021), understanding of this information by farm staff, and then uptake of these recommendations still remains a challenge that impedes progression as an industry. Perinatal calf mortality worldwide has been reported to be between 2.4 and 9.7\% (Cuttance and Laven, 2019a,b), with one UK paper estimating mortality to be $7.9 \%$, (Brickell et al., 2009), and an Irish study finding average perinatal mortality to be $4.3 \%$ (Mee et al., 2008). Following on from this, a further $6 \%$ of UK dairy calves were found to die within 3 mo of birth (Hyde et al., 2020). Another study conducted on 18 UK farms found that $11 \%$ of dairy heifers died between one month of age and first calving (Brickell and Wathes, 2011), with losses continuing into first lactation when an additional $12.2 \%$ were culled (Esslemont and Kossaibati, 1997). These calf mortalities indicate that, although much is known about the science of calf care, the practical realities of successfully rearing these animals on farm is falling short. Studies from some countries have shown that lower national perinatal mortality is possible, with a country wide retrospective study of French data showing $4.4 \%$ mortality rates in the first month of life (Raboisson et al., 2013), 
and a 2-yr retrospective study from Switzerland showing $2.4 \%$ perinatal mortality (Bleul, 2011).

The environment within which a calf is housed can have a significant effect on health and welfare parameters (Nordlund and Halbach, 2019). There are multiple types of calf housing used on farm, ranging from individual and group hutches, to indoor prefabricated partition pens or larger group pens within sheds, and outdoor pasture-based rearing systems (Brown et al., 2021). Each of these housing types provides its own challenges. Ensuring good ventilation is a key consideration due to its links with respiratory disease from build-up of ammonia, temperature-humidity index, dust particles, and airborne bacteria (Wathes et al., 1984; Kelly et al., 1986; Lago et al., 2006; Louie et al., 2018). Ventilation can be improved through the correct use of positive pressure ventilation tubes. A study by Jorgensen et al. (2017) that assessed risk factors for calf disease across 38 US dairy farms indicated that barns that did not use positive pressure ventilation tubes had $80.6 \%$ increased odds of a calf having pyrexia during a visit. The provision of adequate lighting is also important to enable good visibility of calves for signs of ill health, and also to carry out routine tasks such as feeding and bedding (AHDB, 2017). The prevalence of different housing systems in use across the United Kingdom is currently unknown. This information is, however, required to understand the reasons behind farmer choice, to identify key areas in the housing environment of calves and to improve targeting of knowledge transfer to the industry.

A further aspect of calf housing that has received greater appreciation in the last decade is the effect that individual compared with pair or group housing of calves can have on their social development and welfare. Studies have demonstrated that calves use social learning, whereby the actions of a calf are influenced by watching or interacting with other calves (Keeling and Hurnik, 1996). A key area that this affects is solid feed consumption, with pair-housed calves starting to consume solids at an earlier age and in greater amounts compared with individually housed calves (De Paula Vieira et al., 2010; Mahendran et al., 2021). For example, Costa et al. (2015) found that pair-housed calves consumed $2.2 \pm 0.22 \mathrm{~kg} / \mathrm{d}$ of concentrates compared with only $1.26 \pm 0.33 \mathrm{~kg} / \mathrm{d}$ for individually housed calves. Furthermore, calf health was not compromised in these paired systems (Bučková et al., 2021; Mahendran et al., 2021). This trend continues in group housed calves, which have been shown to spend more time eating solids than individually housed calves (19.3 vs. 14.4 $\mathrm{min} / \mathrm{hr}$ ) (Babu et al., 2004). In addition, calves housed in groups demonstrate increased play behaviors, which is seen as a positive indicator of well-being (Spinka et al., 2001), especially when the whole group was fed with high milk allowances of $12 \mathrm{~L} / \mathrm{d}$ (Größbacher et al., 2020). The most recent survey data available from the United Kingdom is from 2010, and indicated that approximately $60 \%$ of calves were housed in individual pens (Marcé et al., 2010). Since this survey, many milk buyers and farm assurance schemes in the United Kingdom have implemented changes as to what they deem to be acceptable calf housing practices. This has mainly been the reduction of individual housing; the effect this has had on the use of different types of calf housing is as yet unknown.

Other important housing management areas include the amount of time a calf spends with the dam, as this is known to affect exposure of calves to pathogens. Neonatal diarrhea is often caused by Escherichia coli, rotavirus, coronavirus, or Cryptosporidium in the first few weeks of life (Bartels et al., 2010), all of which a calf can be exposed to in the calving pen. The situation is similar with herd-level endemic infectious conditions such as Johne's disease, which is thought to have a prevalence of $68.3 \%$ within Great Britain (Velasova et al., 2017). It is known that if exposure to Mycobacterium avium ssp. paratuberculosis occurs at birth, the risk of infection progressing and future bacteria shedding is high, especially in contaminated calving pen environments (Windsor and Whittington, 2010). Recommendations to immediately remove calves from the dam (snatch calving) were therefore established to reduce the risk of infection (Mee, 2008), but the actual uptake of this advice across UK farms is unknown.

Feeding practices are another area of calf rearing where more recent literature has highlighted the oftenchronic underfeeding that occurs in many management systems due to adoption of restricted milk feeding practices. One recent study found that 302/508 (59.6\%) of Norwegian herds fed less than the recommended $8 \mathrm{~L} /$ d of milk, even though industry guidelines had been in place for over 5 years (Johnsen et al., 2021). It is well documented that feeding higher milk allowances leads to increased productivity and growth (Geiger et al., 2016), while reducing hunger and cross sucking (De Paula Vieira et al., 2008), yet other surveys have also found that calves are often fed lower volumes, such as $5.4 \pm 2.1 \mathrm{~L} / \mathrm{d}$ of milk (Jorgensen et al., 2017).

Selection of the type of calf housing used on a particular farm can be influenced by many factors such as availability of pre-existing housing types, the number of calves needed to be housed, and prior farmer experiences or perceptions around the use of certain types of calf housing. Ritter et al. (2017) demonstrated that farmers do not regularly adopt recommended measures, with attempts to instigate changes in management through generalized arguments often proving insuf- 
ficient to motivate on-farm change. This has also been shown in the control of cattle diseases such as mastitis, where the provision of technical information about best practices alone was not sufficient to improve mastitis management. Combining this with an understanding of farmer mindset about perceived threats and efficacies of measures did, however, affect behavioral determinants of successful mastitis management strategies (Jansen and Lam, 2012). Another example of this comes from Robinson (2020), who found that "people factors" were important influences on the success of disease management with respect to Johne's disease control in the United Kingdom. The degree to which the farmers perceived the disease to be a priority, and for the proposed control strategies to be considered feasible, were both important. Being able to identify and appreciate reasons for farmer held perceptions and the effect this might have on their decision making in relation to the type of calf housing used could therefore be important for the improvement of calf health (Rose et al., 2018).

The main objective of this study was to establish a baseline for current calf management practices in the United Kingdom, particularly pertaining to calf housing systems and management decisions. It also aimed to determine farmer perceptions surrounding individual and group calf housing, including their advantages and disadvantages.

\section{MATERIALS AND METHODS}

\section{Survey}

A questionnaire survey was developed that contained 48 questions (15 open, 33 closed). The open questions allowed respondents to provide information without restricting their opinions (Creswell and Clark, 2017). The first section collected general farm information (e.g., location, type of farm, milk buyer), and demographics of the respondent (e.g., age, role on the farm, number of employees). The questionnaire then collected more specific herd details (e.g., breed, herd size, calving pattern, tuberculosis test status under current UK legislation), before moving on to specific questions concerning calf rearing (e.g., who was responsible for calf rearing, how the bull calves were dealt with, age of calf when separated from dam, calf feeding and weaning strategies). The final part of the survey collected information specifically on calf housing (e.g., how the heifer calves were housed, bedding type, disinfection protocols, and farmer perceptions on different types of calf housing). The draft survey was reviewed by a panel of dairy experts (project supervisors and J. Gibbons, AHDB Dairy, Stoneleigh Park, UK), before being piloted with a group of 5 dairy farmers at a local veterinary group calf meeting. Some minor revisions were made to the structure of several questions before the survey was finalized (online Supplemental File S1; https://doi .org/10.6084/m9.figshare.16856518; Mahendran, 2021). The survey was then created using a proprietary online survey tool (Jisc); therefore, no manual data entry was required. Ethical approval was provided by the Royal Veterinary College Social Sciences Research Ethical Review Board (URN SR2019-0369), with all data being anonymized.

\section{Distribution}

The target population was any dairy farmer in the United Kingdom who reared their own heifer calves. The number of dairies in the United Kingdom was estimated to be around 12,000 (AHDB, 2018), although there were no available data to identify what proportion of these do not rear their own replacement heifers. The survey was available online and was voluntary. It was distributed via social media (Facebook, Twitter) and online forums (AHDB Dairy, National Farming Union, Scottish Dairy Hub, and The Farming Forum). A link to the online survey was also distributed through 6 local veterinary practices (selected by convenience sampling) and university veterinary practice newsletters. Due to anonymization, we were unable to screen for multiple responses from the same farming enterprise.

\section{Statistical Analysis}

A sample size estimation considered the proportion of respondents needed to describe the prevalence of farms housing calves in individual pens using an assumed proportion of farms of 0.6 (Marcé et al., 2010) and an acceptable error of 0.1 , with a $95 \%$ confidence interval. This indicated the need for a minimum of 96 survey respondents.

Results of the survey were exported from the online software into Microsoft Excel 2016 (Microsoft Corp.) for analysis. The open question answers regarding farmer opinions about types of calf housing were categorized into themes using thematic analysis methodology (Attride-Stirling, 2001). This involved data reduction whereby we identified specific anecdotes (e.g., the respondent preferred individual housing to allow monitoring of feed intakes) within the responses that could be coded into keywords to allow basic themes to be established within the responses. Farmers could respond with multiple themes within the same answer. These results are reported within tables in the results.

Data analysis was performed using SPSS (Version 26, IBM). Descriptive statistics were computed for each question to determine the frequency distribution of the 
outcomes, with means and corresponding standard deviations calculated for continuous variables. Pearson's chi-squared tests were performed to analyze the relationship between farmer opinions on calf housing type compared with the type of housing they themselves used. Continuous numerical variables were screened for normality using Q-Q plots, and then linear regression models were fitted to investigate associations between numerical variables. Multinomial logistic regression models were fitted to investigate the association between different categorical variables. The significance level was set at $P \leq 0.05$.

\section{RESULTS AND DISCUSSION}

This survey focused on determining the preweaning calf management and housing methods used by dairy farmers who rear their own calves within the United Kingdom, as well as to capture farmer perceptions surrounding the use of different housing facilities for calves. An understanding of current management practices and farmer perceptions can provide information on farmer decision making and help to identify areas for veterinarians to focus their farmer education, and for industry to develop tools and educational programs to improve overall calf health and welfare.

\section{Participants and Farm Demographics}

The survey was open between October 23, 2019, and December 31, 2020. A total of 216 surveys were completed, with a response rate for participants completing a survey once they had clicked the online link being $43 \%$. This was similar to that reported by other farmer surveys (Bertulat et al., 2015; Shivley et al., 2019). The sole access to the survey was through the internet and distribution was aided by social media. It is therefore possible that there was a bias toward participants with easy internet access and who were regular users of social media. In addition, the surveys were completed by self-reporting of respondents, which could have been associated with misinterpretation of questions and recall bias (Coughlin, 1990).

Responses were received from all parts of the United Kingdom (Figure 1) and the respondent demographics are provided in Table 1. In summary, the largest group of respondents were aged 40 to $59 \mathrm{yr}(94 / 216$, $43.6 \%$ ), with most respondents having spent more than $20 \mathrm{yr}$ working in the dairy industry $(131 / 216,60.6 \%)$. Many of the respondents were farm owners or tenants $(140 / 216,64.8 \%)$. There was a median number of 3 full-time employees (range 1-40) on respondents' farms, with a small number of larger farms having more employees (Table 2).
The respondents were predominantly from dairyonly farms $(139 / 219,64.4 \%)$ and were producing milk under conventional (nonorganic) regulations (201/216, $93.1 \%$ ), meaning that standard drug withhold times were applied. Milk was produced for a range of different milk buyers (Table 3). The modal breeds of cow that respondents farmed were Holstein Friesian (HF) or HF crossbred cattle 105/216 (48.7\%). The modal size of the milking herd was 201 to 250 dairy cows $(24 / 216$, $11.1 \%)$, with a total of $52.3 \%(113 / 216)$ of respondents having a herd size between 101 and 400 cows; only 12 respondents had a milking herd size greater than 1,000 cows (Figure 2). The modal 305-d milk yield of the cattle was between 8,001 and 10,000 L (Figure 3). The farms were predominantly all year-round calving herds $(129 / 216,59.7 \%)$, and the majority were not under tuberculosis restrictions $(179 / 216,82.9 \%)$, meaning that they did not have any cattle testing positive for Mycobacterium bovis through the use of a single intradermal comparative cervical tuberculin test. All of

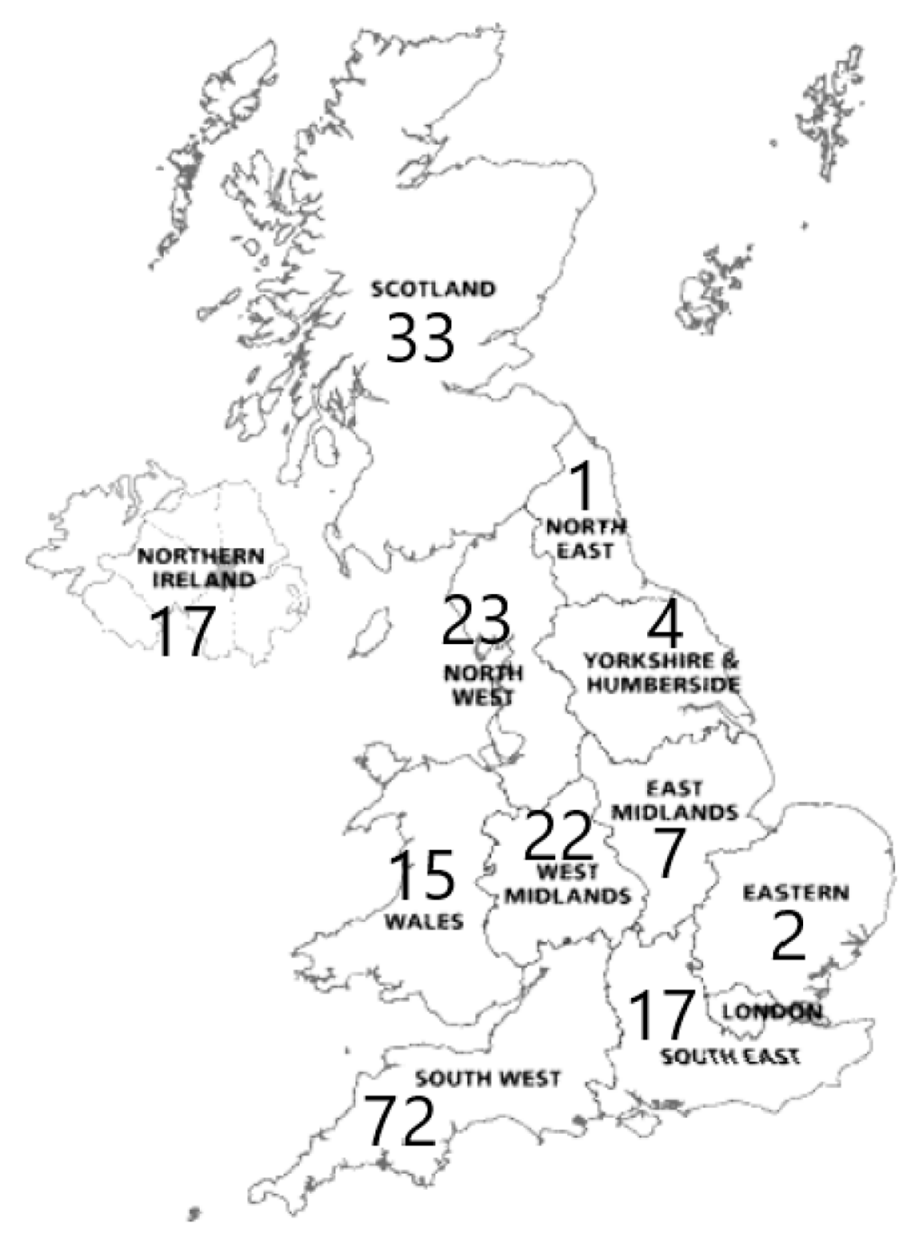

Figure 1. A map of the United Kingdom indicating the total number of survey respondents from each region of the country. 
Table 1. Summary information on survey respondent demographics

\begin{tabular}{lrr}
\hline Variable & Frequency $^{1}$ & Percentage \\
\hline Age range of respondent, yr & 2 & \\
Under 20 & 38 & 0.9 \\
20-29 & 46 & 17.6 \\
$30-39$ & 55 & 21.3 \\
$40-49$ & 39 & 25.5 \\
$50-59$ & 16 & 18.1 \\
60 or over & 20 & 7.4 \\
No answer & & 9.3 \\
Time working in the dairy & & \\
industry, yr & 7 & \\
$0-3$ & 15 & 3.2 \\
4-7 & 14 & 6.9 \\
8-11 & 19 & 6.5 \\
12-15 & 27 & 8.8 \\
16-20 & 131 & 12.5 \\
N0 & 3 & 60.6 \\
No answer & & 1.4 \\
Oole on farm & 140 & \\
Mwner or tenant & 25 & 64.8 \\
Manager & 12 & 11.6 \\
Herdsman & 9 & 5.6 \\
Worker & 29 & 4.2 \\
Family member working & & \\
on farm & 1 & 0.5 \\
No answer & & \\
\hline
\end{tabular}

${ }^{1} \mathrm{n}=216$ farms.

these parameters are representative of the average UK dairy population (AHDB, 2018).

\section{Calf Rearing Staff}

There were several different people reported to be responsible for the day-to-day care of the calves, with $33.3 \%(72 / 216)$ being the farm owner, $31.1 \%(67 / 216)$ being a farm worker, and $25.5 \%(55 / 216)$ being a family member. The majority of calf carers originated from the United Kingdom $(189 / 216,87.5 \%)$ and were male $(55.6 \%, 120 / 216)$, which is in agreement with findings by Sischo et al. (2019) who identified that $83.3 \%$ of calf managers and $96.2 \%$ of calf feeders in the United States were male. However, on farms with a family member caring for the calf, the majority of rearers were female $(31 / 52,59.6 \%)$.

There was a significant association between the size of the farm and the person responsible for calf management, with the owner more likely to be responsible on smaller farmers with lower cow numbers, and larger

Table 2. Summary information on the number of farm employees that respondents had working on their farms

\begin{tabular}{lcccc}
\hline Employee descriptor & Mean & SD & Median & Range \\
\hline Full-time employees & 4.3 & 1.3 & 3 & $0-40$ \\
Part-time employees & 1.8 & 1.4 & 1 & $0-7$ \\
Unpaid assistance & 0.9 & 1.1 & 1 & $0-9$ \\
\hline
\end{tabular}

farms more likely to have an employee rearing the calves $(P<0.01)$. The employment of calf-specific personnel has also been demonstrated on large dairy farms in other countries (Sischo et al., 2019), and may lead to increased specializations of staff skills, and the ability of veterinary practices to target training courses.

The person responsible for making health decisions for the calves was predominantly reported to be the farm owner $(103 / 216,47.7 \%)$, followed by a family member $(46 / 216,21.3 \%)$, and then farm workers $(39 / 216,18.1 \%)$. Only $1.4 \%(3 / 216)$ of farms regularly involved their veterinary practice in making calf health decisions. This low level of regular veterinary involvement means that choices regarding antimicrobial use are being made by farm staff. This highlights the importance of appropriate training for key farm staff

Table 3. Summary information on farm demographics

\begin{tabular}{|c|c|c|}
\hline Variable & Frequency $^{1}$ & Percentage \\
\hline \multicolumn{3}{|l|}{ Type of farm } \\
\hline Dairy & 139 & 64.4 \\
\hline Dairy and beef & 45 & 20.8 \\
\hline Dairy and sheep & 15 & 6.9 \\
\hline Other & 16 & 7.4 \\
\hline No answer & 1 & 0.5 \\
\hline \multicolumn{3}{|l|}{ Type of dairy enterprise } \\
\hline Conventional & 201 & 93.1 \\
\hline Organic & 12 & 5.6 \\
\hline In conversion to organic & 1 & 0.5 \\
\hline Other & 12 & 5.6 \\
\hline No answer & 1 & 0.9 \\
\hline \multicolumn{3}{|l|}{ Milk buyer } \\
\hline Arla & 63 & 29.2 \\
\hline Dairy Crest & 6 & 2.8 \\
\hline First Milk & 9 & 4.2 \\
\hline Muller & 56 & 25.9 \\
\hline Other & 68 & 31.5 \\
\hline Prefer not to say & 10 & 4.6 \\
\hline No answer & 4 & 1.9 \\
\hline \multicolumn{3}{|l|}{ Predominant herd breed } \\
\hline Ayrshire & 3 & 1.4 \\
\hline British Friesian crossbred & 23 & 11.1 \\
\hline Holstein & 53 & 24.5 \\
\hline Holstein Friesian crossbred & 105 & 48.7 \\
\hline Jersey crossbred & 7 & 3.2 \\
\hline Kiwi crossbred & 14 & 6.5 \\
\hline Other & 9 & 4.2 \\
\hline \multicolumn{3}{|l|}{ Calving pattern } \\
\hline All year round & 129 & 59.7 \\
\hline Autumn block & 40 & 18.5 \\
\hline Spring block & 22 & 10.2 \\
\hline Multiblock & 22 & 10.2 \\
\hline & 3 & 1.4 \\
\hline \multicolumn{3}{|l|}{ TB restrictions in place ${ }^{2}$} \\
\hline Yes & 36 & 16.7 \\
\hline No & 179 & 82.9 \\
\hline No answer & 1 & 0.5 \\
\hline
\end{tabular}

${ }^{1} \mathrm{n}=216$ farms.

${ }^{2}$ In the United Kingdom, farms are routinely tested for the presence of tuberculosis (TB), and if positive cattle are identified, animal movement restrictions are placed on the farm, which might affect calf management. 


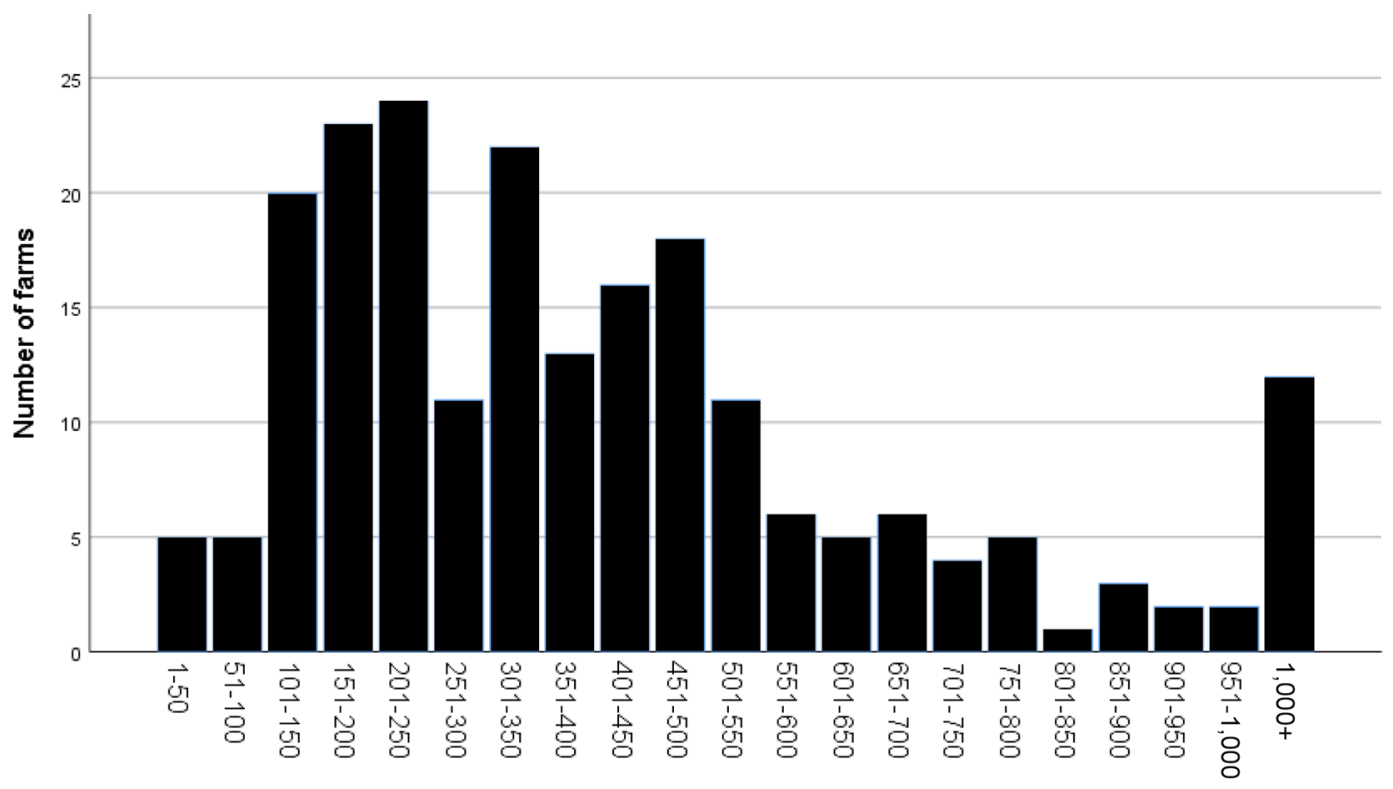

Number of dairy animals in the herd

Figure 2. Distribution of herd size in the survey $(\mathrm{n}=216$ farms).

to avoid misuse of antimicrobials, with multiple studies showing there is still widespread inappropriate use of antimicrobials for conditions such as calf diarrhea (Friedman et al., 2007; Habing et al., 2016). Development and implementation of standard operating procedures (SOP) in conjunction with veterinary practices is becoming more common place and even a requirement of some milk contracts, but SOP must provide details on how to identify calves that require treatment, and not just treatment information such as drug, dose, and route of administration (Habing et al., 2016).

\section{General Management and Feeding of Preweaning Calves}

The modal number of preweaning calves on farm at any one time was reported to be between 21 and 60 calves $(96 / 216,44.4 \%)$. The majority of farms sold their dairy bull and beef calves before weaning (144/216, $66.7 \%)$, with a further $27.3 \%(59 / 216)$ rearing them on farm until after weaning. However, 5 respondents stated that they still euthanized their dairy bull calves on farm; of those, 3 farms kept predominantly HF cows, one Jersey, and one New Zealand cross breeds. This low number of farms euthanizing bull calves may be due to ongoing changes in some milk contracts and Red Tractor guidelines (a UK-based farm and quality food assurance scheme providing guidance on minimum standards for animal care, www.redtractorassurance.org .uk), as well as promotion of sexed semen and demand for healthy and viable bull calves that can be sold onto rearing units for beef production. However, the destination of bull calves leaving the farm was not collected, so some respondents may have sent their calves to abattoir (either direct or via a market) before weaning, thereby still slaughtering bull calves at a young age. Admission by a small number of UK farmers that on-farm euthanasia still occurs is nevertheless worrying for the industry. Bull calf euthanasia is still widespread in other countries such as Ireland (Balzani et al., 2021) and New Zealand (Boulton et al., 2020) due to the lower value of male dairy calves for beef production, the lack of viable veal industries in these countries, and the use of seasonal calving patterns leading to flooding of the market (Fisher et al., 2017). It is encouraging that $80.6 \%$ of respondents reported treating their bull calves in the same way as their replacement heifer calves while on farm, suggesting the perceived value of these bull calves has increased, with approximately $50 \%$ of UK beef now originating from dairy animals (Brown et al., 2020). This is higher than in other countries, with France only using 18\% (Fossaert et al., 2020) and Sweden using $12 \%$ (Clasen et al., 2019) of beef from dairy. However, the perceived value of UK bull calves is in contrast to concerns noted by a survey of 33 Canadian cattle veterinarians, who felt that bull calves often received poor colostrum and nutrition management compared with heifers (Sumner and von Keyserlingk, 2018).

Within both general farming practice and the literature there is still a lack of consensus around how and when to separate cows from calves. A recent review by Meagher et al. (2019) found evidence to support early 
cow-calf separation led to less acute distress, but longer contact did promote more normal social behavior. Another review of 70 papers by Beaver et al. (2019) found that there was no beneficial effect of early separation on calf respiratory or enteric health. In addition, surveys on public perception around cow-calf separation has indicated that between $44 \%$ (Ventura et al., 2013) and $69.2 \%$ of the public (Hötzel et al., 2017) were against early separation. This negative perception of early cowcalf separation was compounded by calves then being housed in individual pens (Ventura et al., 2013). In our survey, there was variation in the time that the calf was left with the dam after birth, with $15.3 \%(33 / 216)$ snatch calving (defined as immediate removal from the dam), 38.8\% (84/216) separating them within 12 $\mathrm{h}, 26.4 \%(57 / 216)$ separating them within $24 \mathrm{~h}$, and $11.6 \%(25 / 216)$ separating them within 36 to $48 \mathrm{~h}$ after birth. This is in agreement with another UK study which found that the modal time for cow-calf separation on 11 dairy farms was $12 \mathrm{~h}$ after birth (Johnson et al., 2017). The longest period of time a calf and dam were left together in this study was reported to be $5 \mathrm{~d}$.

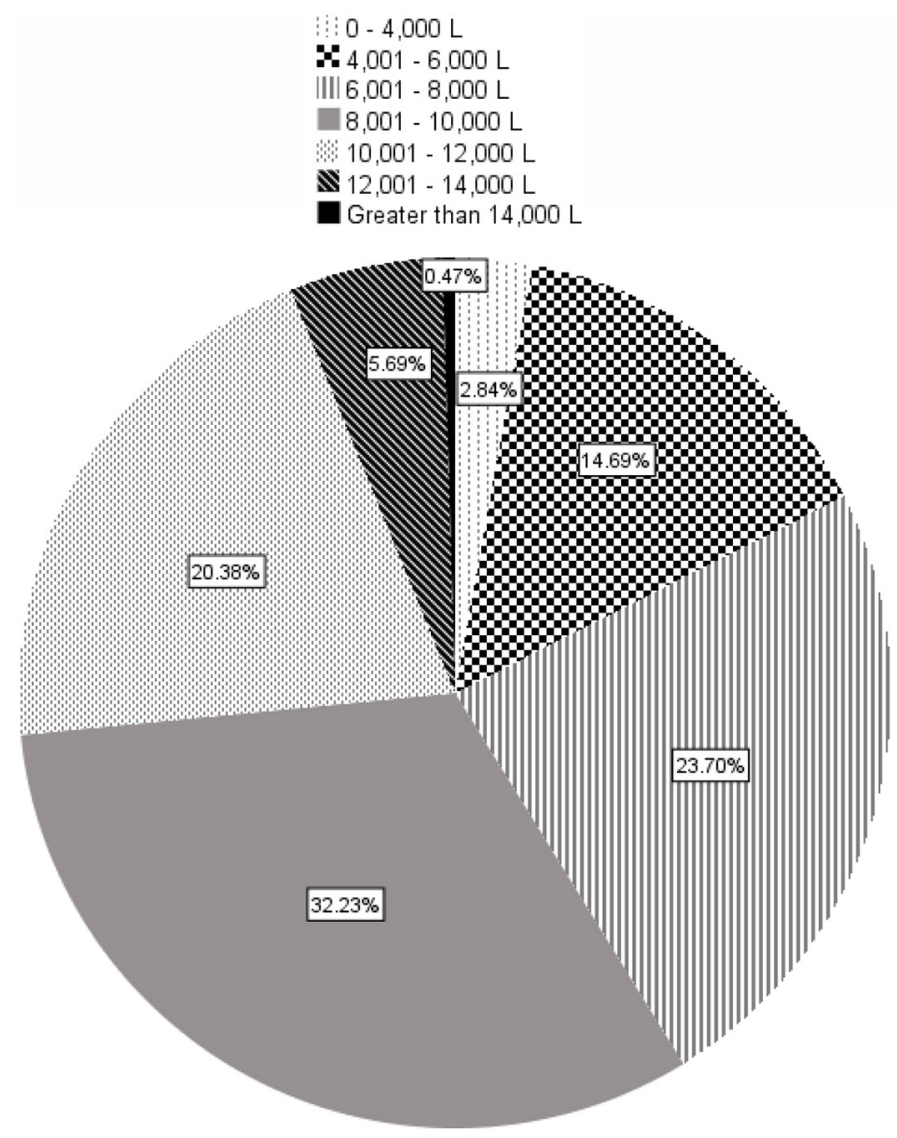

Figure 3. Average 305-d milk yields of respondents $(n=216$ farms).
These UK figures contrast with reports from the US that found the average time from birth to removal of the calf from the dam was $1.7 \mathrm{~h}$ (range 0-6 h; Jorgensen et al., 2017). Snatch calving is often considered as a way to reduce the risk of Johne's disease transmission to the calf, but this is thought to be due to removal of the calf from an environment contaminated with adult cow manure rather than from contact with the dam herself (Beaver et al., 2019). In some organic systems, keeping the calf with the dam for longer periods is considered to encourage natural behavior and therefore provide higher welfare (Ellingsen et al., 2012), although respondents running organic systems in this survey did not keep calves and dams together for longer than those using conventional systems.

The information considering milk feeding of calves is shown in Table 4. The majority of calves were fed using calf milk replacer $(114 / 216,52.8 \%)$, with the remaining farmers feeding either fresh bulk tank milk, acidified bulk tank milk, high SCC milk or waste antimicrobial milk. The median reported concentration of milk powder was $150 \mathrm{~g} / \mathrm{L}(69 / 114,47.9 \%)$ with a mean concentration of $161 \mathrm{~g} / \mathrm{L}$ (range 60-750 g/L). A concentration of $135 \mathrm{~g} / \mathrm{L}$ mimics the DM content of whole milk, with concentrations of $180 \mathrm{~g} / \mathrm{L}$ and above leading to high osmolality and potential compromise of gastrointestinal function (Wilms et al., 2019). Of the organic farms, $50.0 \%(6 / 12)$ of farms fed fresh bulk tank milk, which was significantly different to conventional herds $(P=0.013)$, where only $25.4 \%$ (51/201) fed fresh bulk tank milk. Eight farmers specified that they fed waste antibiotic milk to calves, which is known to affect the rumen microflora (Li et al., 2019) and can increase the presence of antimicrobial resistant bacteria found in calf feces (Maynou et al., 2017). However, this is less than the antibiotic milk feeding reported in Canada of $20 \%$ (Medrano-Galarza et al., 2017), and in Sweden of $56 \%$ (Duse et al., 2013).

The majority of calves were fed manually twice daily $(189 / 216,87.5 \%)$, from either individual teat feeders $(85 / 216,39.4 \%)$, group teat feeders $(50 / 216,23.1 \%)$, or individual buckets $(49 / 216,22.7 \%)$. These figures are similar to those found by a large-scale survey from Canada, whose respondents reported that $86 \%$ of calves that were manually fed were provided milk twice daily, and $53 \%$ of calves were fed via teats (Medrano-Galarza et al., 2017). This indicates that bucket feeding may be declining, with the use of teats known to reduce cross sucking by extending the time taken to consume milk meals (Salter et al., 2021).

An open question was used in the survey to determine the volumes of milk fed to calves. The responses indicated that the majority of farmers initially fed either $4 \mathrm{~L}$ of milk per day $(66 / 216,30.6 \%)$ or $6 \mathrm{~L} / \mathrm{d}(47 / 216$, 
$21.8 \%$ ), but a small number of farmers initially only provided 2 to $3 \mathrm{~L} / \mathrm{d}(28 / 216,13.0 \%)$. This range in milk feeding volumes is in agreement with findings reported by Hyde et al. (2021) across 30 UK farms, and indicates that restricted milk feeding protocols are still highly prevalent, which also agrees with recent findings from Norway (Johnsen et al., 2021). This can be

Table 4. Milk feeding management of calves

\begin{tabular}{|c|c|c|}
\hline Variable & Frequency $^{1}$ & Percentage \\
\hline \multicolumn{3}{|l|}{ Type of milk fed } \\
\hline Calf milk replacer powder & 114 & 52.8 \\
\hline Fresh bulk tank milk & 58 & 26.9 \\
\hline Acidified bulk tank milk & 3 & 0.9 \\
\hline High-SCC milk & 11 & 5.1 \\
\hline Waste antimicrobial milk & 8 & 3.7 \\
\hline No answer & 23 & 10.6 \\
\hline \multicolumn{3}{|l|}{ Milk feeding frequency } \\
\hline Manually once daily ${ }^{2}$ & 1 & 0.5 \\
\hline Manually twice daily & 189 & 87.5 \\
\hline Manually 3 times daily & 2 & 0.9 \\
\hline Automated calf feeder & 5 & 2.3 \\
\hline Ad libitum feeder & 4 & 1.9 \\
\hline Other & 6 & 2.8 \\
\hline No answer & 9 & 4.2 \\
\hline \multicolumn{3}{|l|}{ Milk feeding method } \\
\hline Individual bucket & 49 & 22.7 \\
\hline Shared bucket & 2 & 0.9 \\
\hline Individual teat feeder & 85 & 39.4 \\
\hline Group teat feeder & 50 & 23.1 \\
\hline Other & 11 & 5.1 \\
\hline No answer & 19 & 8.8 \\
\hline \multicolumn{3}{|l|}{$\begin{array}{l}\text { Total volume of milk the calf } \\
\text { was initially fed (L) }\end{array}$} \\
\hline 2 & 14 & 6.5 \\
\hline 3 & 14 & 6.5 \\
\hline 4 & 66 & 30.6 \\
\hline 5 & 36 & 16.7 \\
\hline 6 & 47 & 21.8 \\
\hline 7 & 7 & 3.2 \\
\hline 8 & 5 & 2.3 \\
\hline Ad libitum & 14 & 6.5 \\
\hline \multicolumn{3}{|c|}{$\begin{array}{l}\text { Total maximum volume of milk } \\
\text { fed per day }(\mathrm{L})\end{array}$} \\
\hline 2 & 2 & 0.9 \\
\hline 3 & 14 & 6.5 \\
\hline 4 & 12 & 5.6 \\
\hline 5 & 30 & 13.9 \\
\hline 6 & 56 & 25.9 \\
\hline 7 & 12 & 5.6 \\
\hline 8 & 22 & 10.2 \\
\hline Ad libitum & 14 & 6.5 \\
\hline \multicolumn{3}{|c|}{$\begin{array}{l}\text { Does farmer increase milk feeding } \\
\text { in cold weather? }\end{array}$} \\
\hline Yes & 62 & 28.7 \\
\hline No & 90 & 41.7 \\
\hline No answer & 64 & 29.6 \\
\hline \multicolumn{3}{|l|}{ Use of calf jackets } \\
\hline Yes & 121 & 56 \\
\hline No & 80 & 37 \\
\hline Other & 12 & 5.6 \\
\hline No answer & 3 & 1.4 \\
\hline
\end{tabular}

${ }^{1} \mathrm{n}-216$ farms.

${ }^{2}$ Only legally permissible in the United Kingdom for calves older than 4 wk. considered as underfeeding of calves, with feeding of more milk resulting in higher weight gains both before and after weaning (Rosenberger et al., 2017). Given that $87.5 \%$ of farmers fed their calves twice daily, the limited milk volumes may have been due to concerns over a calf's ability to handle larger volumes of milk per feed. However, calves fed higher milk volumes from the first week of life have been shown to adapt well to larger milk volume feeding (4-L feeds twice per day), with no effect on insulin sensitivity (MacPherson et al., 2019). A study by Curtis et al. (2018) has also suggested that feeding in the first $3 \mathrm{wk}$ of life had the biggest effect on growth, with this study demonstrating a $0.55 \mathrm{~kg} / \mathrm{d}$ difference in growth rates between calves fed ad libitum compared with $5 \mathrm{~L} / \mathrm{d}$ during this time. The abomasal volume in calves around 3 wk of age has also been shown to expand to contain voluntary milk feeds of up to $6.8 \mathrm{~L}$, with no signs of abdominal discomfort or milk flow back into the rumen (Ellingsen et al., 2016). This indicates that increasing milk volumes to 5 to $6 \mathrm{~L}$ per feed in calves from $3 \mathrm{wk}$ of age is possible. Increasing meal frequency can also be a way to increase milk intakes, and can be achieved through the use of ad libitum or automatic calf feeders, but only $4.2 \%$ of our respondents were using these.

Most farmers did not measure environmental temperatures in the calf housing $(172 / 216,79.6 \%)$, with the majority of farmers not increasing the milk fed to calves (either volume or concentration of milk) during periods of cold weather. However, $56.0 \%$ did use calf jackets even though there is little evidence to suggest that these improve calf performance (Scoley et al., 2019; Rutherford et al., 2019). Multinomial logistic regression indicated that farmers who group housed their calves ( $>2$ calves) had increased odds of not using calf jackets (OR: $7.14,95 \%$ CI: $1.21-41.07, P=0.028$ ), possibly due to the perception that group housed calves can huddle together for warmth.

A total of $55.6 \%(120 / 216)$ of farmers reported that they weighed their calves, with the main method being either a weigh band $(73 / 120,60.8 \%)$ or a weigh scale $(38 / 120,31.7 \%)$. Calves tended to be weighed at birth $(60 / 120,50 \%)$, and at weaning $(55 / 120,45.8 \%)$, with a small number of farms carrying out weekly weighins $(12 / 120,10.0 \%)$. Knowing accurate weights is vital for calculating average daily growth rates which can be used to inform evaluation of calf rearing practices on farm, with a minimum target of $0.7 \mathrm{~kg} / \mathrm{d}$ growth needed if target weights for age at first calving at 24 mo are to be reached (Cooke et al., 2013).

The weaning age for calves on the majority of farms was 8 wk $(71 / 216,32.9 \%)$, with $2.8 \%(6 / 216)$ of farmers targeting 6 wk; $17.6 \%(38 / 216) 9$ wk; $18.5 \%(40 / 216)$ 10 wk; and $15.2 \%(33 / 216) 11$ to 12 wk of age. Linear 
regression indicated that there was no association between the volume of milk a calf was fed and the target weaning age on farm $(P=0.37)$. The modal weaning age of 8 wk of age is in accord with a previous UK study of 11 farms which found that, although most calves were weaned between 60 and $70 \mathrm{~d}$ of age, the actual range was much wider, at 34 to $96 \mathrm{~d}$ of age (Johnson et al., 2017). There is much variation in the literature regarding appropriate weaning ages, but slowly decreasing the milk volumes fed to stimulate solid feed intakes, and increasing the age at which weaning occurs (to $12 \mathrm{wk}$ ) can help to maintain energy intakes over the weaning period, and reduce signs of hunger during and after weaning (de Passillé et al., 2011).

There were 3 main themes that farmers used to decide when to wean their calves: age, weight, and concentrate intake (Figure 4). A total of $31.9 \%(69 / 216)$ of farmers used weight as a factor, with $21.7 \%(15 / 69)$ stating they wanted the calves to have doubled birth weight by weaning. However, 21.7\% (15/69) of these farmers said that they do not actually weigh their calves. This suggests that some farmers estimate calf weights via observation alone, which is likely to be highly inaccurate (van Dijk et al., 2015; Wood et al., 2015). Other farmers specified certain target weights that calves needed to achieve, with the most common for HF breeds being $100 \mathrm{~kg}(16 / 69,23.2 \%)$.

A further $31.0 \%(67 / 216)$ of farmers used age as a factor for weaning, with the range being 6 to $12 \mathrm{wk}$

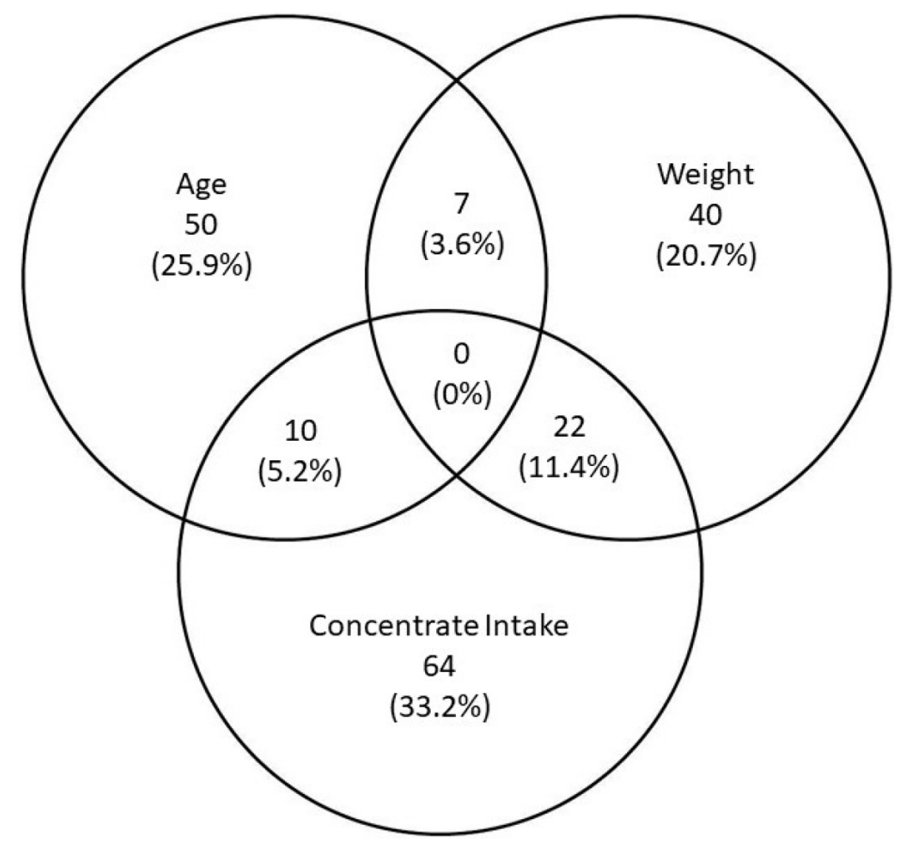

Figure 4. Venn diagram of the criteria farmers used to decide when to wean calves. of age. Age was also reported to be the predominant factor for weaning calves in a large Canadian survey (Medrano-Galarza et al., 2017). Lastly, 44.4\% (96/216) of farmers used the amount of concentrate consumed by the calf as a factor for when to wean, with increased solid feed intake being positively correlated with rumen papillae length (Roth et al., 2009). The range of concentrates consumed per day was specified as between 1 and $4 \mathrm{~kg} / \mathrm{d}$ by weaning, and of these, $52.8 \%(28 / 53)$ specified $2 \mathrm{~kg} / \mathrm{d}$. However, given many of these calves were group housed, it is unclear how farmers were determining individual calf solid feed intakes in an accurate manner. This is likely to result in group weaning strategies that ignore the needs of individual calves, such as weaning the whole group when the youngest calf is at the minimum age. There is some evidence that weaning based on individual concentrate intakes can lower overall milk consumption and maintain similar postweaning weights compared with calves weaned at a fixed age (Benetton et al., 2019).

\section{Housing of Calves}

The majority of farmers housed their calves inside a shed with walls $(162 / 216,75.0 \%)$, with a further $15 / 216$ $(6.9 \%)$ housing them under a roof but in a structure with no walls. The remaining farmers kept the calves outside in hutches $(35 / 216,16.2 \%)$. Chi-squared analysis indicated no association between the type of housing used and the calving pattern of the herd $(P=0.31)$.

The majority of farmers used unchopped straw to bed their calves $(184 / 216,85.2 \%)$, with the remaining farmers using either chopped straw $(20 / 216,9.3 \%)$, sawdust or shavings $(5 / 216,2.3 \%)$, or another substrate $(4 / 216$, $1.9 \%)$. This is in agreement with findings by Jorgensen et al. (2017) who demonstrated that on 38 farms in the United States, $78 \%$ of calf pens used straw bedding, with the remaining using wood shavings or cornstalks. Bedding type has been shown to influence lying behavior in calves, with decreased time spent lying when the bedding is $<59 \% \mathrm{DM}$ (wet), and a preference for soft, dry lying surfaces (Camiloti et al., 2012).

Only $65.3 \%(141 / 216)$ of farmers bedded their calves on a daily basis, with others providing bedding every other day $(35 / 216,16.2 \%), 3$ times/wk $(18 / 216$, $8.3 \%)$, twice per week $(10 / 216,4.6 \%)$, or as needed $(10 / 216,4.6 \%)$. Farmers were asked how calf housing was cleaned out between different calves utilizing it, with a summary given in Table 5 . There was a wide range of cleaning techniques used in housing between batches of calves, with only a low number of farmers using disinfection of the housing materials $(38.0 \%)$, or of the ground $(47.7 \%)$. Together with bedding rates, these findings may explain the relatively high preva- 
Table 5. Summary of cleaning techniques used between calves using the same housing ${ }^{1}$

\begin{tabular}{lcc}
\hline Cleaning technique & Frequency & Percentage \\
\hline All bedding was removed & 155 & 71.8 \\
Ground was cleaned & 98 & 45.4 \\
Ground was disinfected & 103 & 47.7 \\
Housing material was washed & 107 & 49.5 \\
Housing material was disinfected & 82 & 38.0 \\
Area was left unused for a period of time & 89 & 41.2 \\
Only additional fresh bedding was put on & 28 & 13.0 \\
$\quad$ top of existing bed & 11 & \\
No response & & 5.1 \\
\hline
\end{tabular}

${ }^{1}$ Denominator population was 216 farmers, but respondents could select multiple answers.

lence of Cryptosporidiosis (www.gov.uk/government/ collections/animal-disease-surveillance-reports) in the United Kingdom, with reported prevalence of up to $78 \%$ (Brainard et al., 2020).

The majority of farmers housing calves within a shed did not use any mechanical ventilation (120/157, $76.4 \%)$. Although we have no information on prevalence on these farms, the incidence of bovine respiratory disease is high on UK dairy farms, with a reported incidence of $46 \%$ in preweaning calves (Johnson et al., 2017). It is known that poor shed ventilation can have negative effects on respiratory health and the spread of respiratory pathogens (Anderson and Bates, 1979). Given that $19.2 \%$ of farmers planned to make ventilation changes to their existing calf housing in the next 12 mo, this does suggest that the negative effects of poor ventilation are appreciated by some farmers. Many farmers did have artificial lighting (130/157, 82.8\%), which was predominantly used in the winter periods at feeding time.

The most prevalent initial type of housing used for newborn calves was individual housing (83/216, $38.4 \%$ ), with pair housing used by $23.1 \%(50 / 216)$, and group housing of greater than 2 calves used by $35.6 \%$ $(77 / 216)$. This is a decrease in individual housing compared with findings of $60 \%$ by Marcé et al., (2010), and is likely due to recent changes in milk buyer policies in the United Kingdom, with many companies now stipulating the use of pair or group pens from either birth or within the first few weeks of life. This is supported by our survey finding that $31.1 \%$ of farmers had made calf management changes away from individual calf pens in the previous 24 mo.

Following the initial period after birth, some farmers then changed their calf housing type before weaning (Table 6). A total of $87.5 \%(189 / 216)$ of farmers reported that they used some form of group housing preweaning, with the median group size being 7 calves, and the range being 2 to 42 calves.
Table 6 . Change in calf housing type before weaning

\begin{tabular}{lcc}
\hline Change in calf housing type & Frequency $^{1}$ & Percentage \\
\hline From individual into pair pen & 11 & 5.1 \\
From individual into > calf group pen & 45 & 20.8 \\
From pair into group pen & 25 & 11.6 \\
No change in housing group & 87 & 40.3 \\
No answer & 48 & 21.9 \\
\hline${ }^{n}=216$ farmers & &
\end{tabular}

For the farmers who used individual calf housing $(83 / 216,38.4 \%)$, there was a wide range of housing type or design used (Table 7 ). The majority of the individual pens used were reported to allow both visual and tactile contact between calves $(72 / 83,86.7 \%)$, but $13.3 \%$ $(11 / 83)$ only permitted visual contact between pens. This is in direct violation of EU directive 97/2/EC. One possible reason farmers chose to house calves in this way was that they felt individual housing gave better health benefits and biosecurity for calves (41.2\%), which could possibly be compromised by increased pathogen spread if the calves could make direct contact. In addition, $48.2 \%$ of farmers using individual housing reported that they would not try pair housing as they thought that individual pens provided better management at the individual calf level, with less disease and no cross sucking (Table 8). However, surprisingly, the number of farmers that perceived navel sucking to be a problem in group housing was relatively low at $11.6 \%$. Cross sucking is a non-nutritive sucking activity that is increased when feeding methods result in calves spending only short periods sucking when feeding, leading to calves sucking on other pen contents or other calves (Rushen and de Passillé, 1995). This suggests that either the feeding methods used in the group housing provided satisfaction of the innate calf requirement to suck, or there was a lack of farmer time observing calves meaning that this behavior was missed in groups.

During the immediate postweaning period, the majority of farmers housed their calves in group loose pens $(172 / 216,79.6 \%)$, followed by grazing of calves $(20 / 216,9.3 \%)$ or use of group hutches $(10 / 216,4.6 \%)$.

Table 7 . The type of individual calf pen used by farmers

\begin{tabular}{lcc}
\hline Type of individual calf pen used & Frequency $^{1}$ & Percentage \\
\hline Agri-plastics hutch & 7 & 8.4 \\
Calf-tel hutch & 23 & 27.7 \\
Pens with metal bar dividers & 41 & 49.4 \\
Pens with solid plastic walls & 7 & 8.4 \\
Pens with solid wooden walls & 3 & 3.6 \\
Other & 2 & 2.4 \\
\hline
\end{tabular}

${ }^{1} \mathrm{n}=83$ farmers. 
Farmers were asked whether they had made any changes to their calf housing in the last $24 \mathrm{mo}$, with $34.3 \%(74 / 216)$ responding yes, and $45.8 \%(99 / 216)$ responding no. Of those farmers that said yes, $31.1 \%$ $(23 / 74)$ had moved from individual to pair or group housing, $18.9 \%(14 / 74)$ had put up a new calf shed, and $17.6 \%(13 / 74)$ had changed their feeding method. Farmers were also asked if they planned to undertake any changes to their calf housing in the next $12 \mathrm{mo}$, with $33.8 \%(73 / 216)$ responding yes, and $49.1 \%(106 / 216)$ responding no. Of those farmers that said yes, $41.1 \%$ $(30 / 73)$ planned to put up a new calf shed, and $19.2 \%$ $(14 / 73)$ planned to make ventilation changes to their existing calf housing.

\section{Farmer Perceptions of Calf Housing}

Farmers were asked to describe their main perceptions of the advantages and disadvantages of individual and group housing for calves. The free text box responses were classified into themes, with the results summarized in Table 9. When interpreting the perceptions of respondents, consideration must be given to the potential for bias, with an increased likelihood for farmers to have positive perceptions about the housing type that they are using. Interestingly, the main benefit reported by $65 \%$ of farmers currently using individual calf pens was the ability to monitor the feeding behavior and health of the individual calf $(P<0.01)$, with $25 / 216$ farmers specifically stating that it is harder to achieve this in group housing. This suggests that the stockmanship ability of farm workers is a significant factor in choosing calf housing type. Possible reasons for this include the ease of feeding $(P<0.01)$, with the ability to leave an individually housed calf unsupervised with its milk feed (potentially to try and save labor and time), and still be able to see how much milk it had consumed. In a pair or group housing situation,

Table 8. Summary of whether farmers using individual calf pens would try pair housing of calves

\begin{tabular}{lcc}
\hline Would farmers try pair housing? & Frequency $^{1}$ & Percentage \\
\hline Yes, to reduce labor and make better & 3 & 3.6 \\
use of space & 6 & 7.2 \\
Yes, to improve social interaction & 9 & 10.8 \\
Yes, milk contract stipulates have to & 11 & 13.3 \\
Yes, other & 4 & 4.8 \\
No, pen design/changes + costs & 24 & 28.9 \\
No, individual management better & & \\
and less disease & 8 & 9.6 \\
No, don't want any cross sucking & 4 & 4.8 \\
No, other & 14 & 16.9 \\
No answer & &
\end{tabular}

${ }^{1} \mathrm{n}=83$ farmers. it would not be possible to tell if one calf had consumed the feed of another calf. Given that reduced feed intakes are one early sign of ill health in a calf, being able to identify these calves with reduced feed intake may be important, and individual housing provides a relatively easy, low skilled way to do this. There was also a trend in farmer perception about the link between an increased risk of disease spread and the use group housing $(P=0.061)$, with $45 \%$ of farmers using group housing reporting it is a problem compared with $30 \%$ of farmers using individual housing. This might suggest that raised disease levels in group housing are a genuine disadvantage rather than just a perception, although most of the literature does not support this (Costa et al., 2016). Another cause for this finding may be linked to a reduced ability of staff to identify ill calves early in the disease course when housed in groups rather than individually. It is possible to identify sick calves in group pens through signs such as longer lying times and reduced activity (Duthie et al., 2021) but this requires high levels of attention to detail by stock people. This highlights an area where staff training could be improved, with selection of appropriate communication strategies by veterinary advisors to engage farmers (Jansen et al., 2010b), and then helping to establish calf management tools such as treatment plans and checklists (Jansen et al., 2010a). Another area that could aid stockmanship in group housing is the adoption of more computerized calf feeders. Their use was found to be low in this survey (only 2.3\%), but they do allow identification of individual calf feeding levels and drinking speeds, which can highlight sick calves up to 3 d earlier than calf personnel (Knauer et al., 2018).

The other highly significant difference in housing perception was that surrounding the ability of calves to interact socially and to have larger space $(P<0.01)$. A total of $44.4 \%$ of farmers currently using group housing considered the lack of social interaction and space to be a significant disadvantage of individual housing, compared with only $12.0 \%$ of people currently using individual housing $(P<0.01)$. This difference may be due to experiences and observations of calf play behaviors by farmers using group housing, with group housed calves often having increased play behaviors associated with more available space (Tapki et al., 2006). Conversely, farmers who use individual pens may not consciously want to acknowledge play activity as being an important aspect of calf behavior due to the animals' reduced ability to demonstrate it in this housing type.

\section{CONCLUSIONS}

This survey has established the prevalence of different calf management strategies currently being used in 
Table 9. Comparison of the perceived benefits of calf housing type for farmers that did and did not use that type of housing; respondents could provide multiple answers, with the denominator population given in brackets ${ }^{1}$

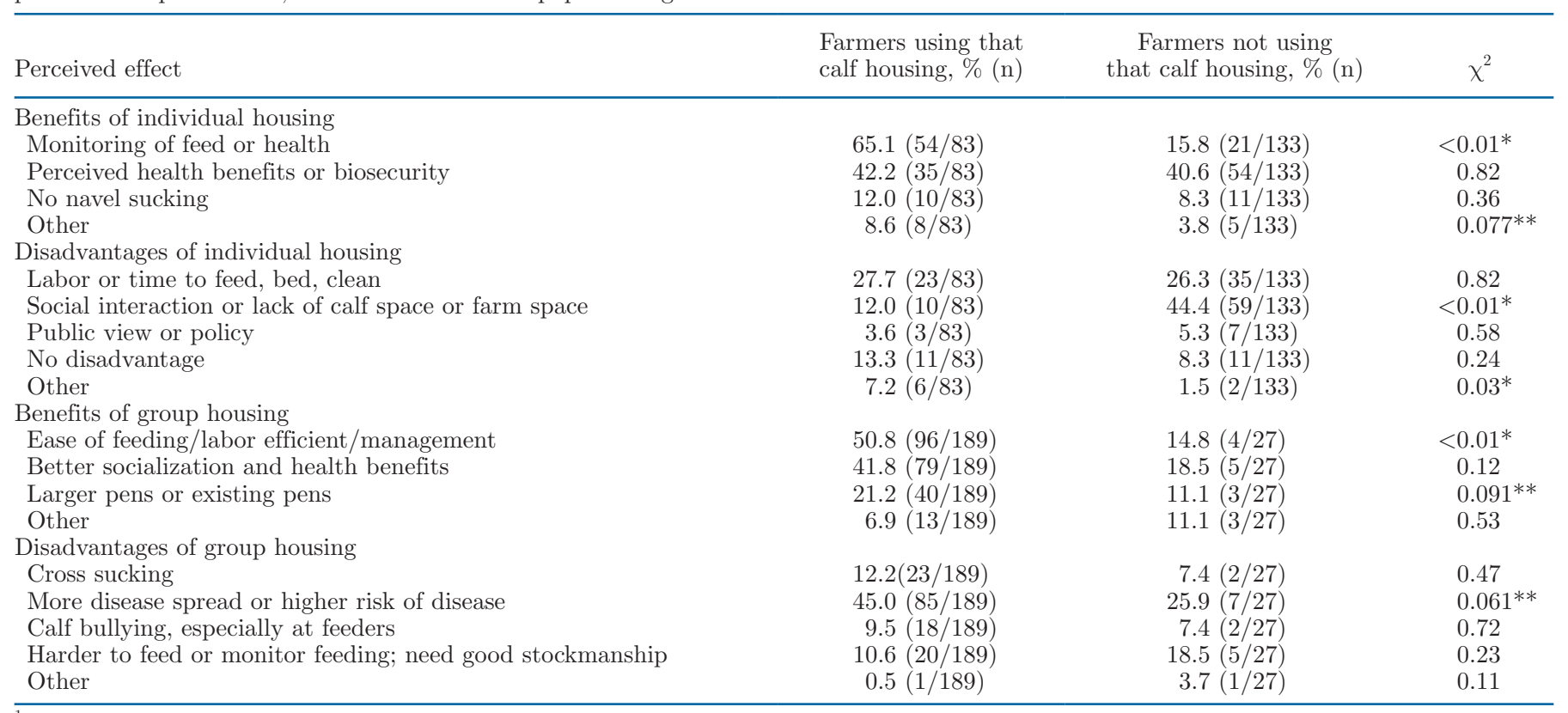

${ }^{1} \mathrm{~A}$ chi-squared comparison was carried out at each variable, with $*$ indicating a significant difference at $P<0.05$ level and $* *$ a trend $P<0.1$.

the United Kingdom. Key areas identified include the low level of regular veterinary involvement in day-today health decision making for calves, highlighting the need for appropriate staff training and SOP to ensure prudent antimicrobial usage while maintaining calf health. The survey also found that restricted calf milk feeding is still highly prevalent along with low levels of euthanasia in bull calves and feeding of antimicrobial waste milk. With regard to housing, there has been a reduction in the use of individual calf pens driven by milk buyer policies, even though farmer perceptions indicated that individual housing can help with calf health and feed monitoring. Our results indicate that this change in calf housing type has an effect on the required stockmanship skills. The study also found that not all farmers provide fresh bedding to calves on a daily basis, and in conjunction with relatively few farmers disinfecting both the calf housing and ground, this highlights an area that could negatively affect calf enteric health.

\section{ACKNOWLEDGMENTS}

Many thanks go to the Barham Benevolent Foundation (London, UK) for their financial support of this study, and AHDB Dairy for their assistance with survey design. The authors have not stated any conflicts of interest.

\section{REFERENCES}

AHDB (Agriculture and Horticulture Development Board). 2017. Better Calf Housing. AHDB.

AHDB (Agriculture and Horticulture Development Board). 2018. UK and EU cow numbers. Accessed Nov. 7, 2019. https://ahdb.org uk/dairy/uk-and-eu-cow-numbers.

Anderson, J. F., and D. W. Bates. 1979. Influence of improved ventilation on health of confined cattle. J. Am. Vet. Med. Assoc. 174:577-580.

Attride-Stirling, J. 2001. Thematic networks: An analytic tool for qualitative research. Qual. Res. 1:385-405. https://doi.org/10 $.1177 / 146879410100100307$.

Babu, L. K., H. N. Pandey, and A. Sahoo. 2004. Effect of individual versus group rearing on ethological and physiological responses of crossbred calves. Appl. Anim. Behav. Sci. 87:177-191. https://doi .org/10.1016/j.applanim.2004.01.006.

Balzani, A., C. Aparacida Vaz do Amaral, and A. Hanlon. 2021. A perspective on the use of sexed semen to reduce the number of surplus male dairy calves in Ireland: A pilot study. Front. Vet. Sci. 7:623128.

Bartels, C. J. M., M. Holzhauer, R. Jorritsma, W. A. J. M. Swart, and T. J. G. M. Lam. 2010. Prevalence, prediction and risk factors of enteropathogens in normal and non-normal faeces of young Dutch dairy calves. Prev. Vet. Med. 93:162-169. https://doi.org/10.1016/ j.prevetmed.2009.09.020.

Beaver, A., R. K. Meagher, M. A. G. von Keyserlingk, and D. M. Weary. 2019. Invited review: A systematic review of the effects of early separation on dairy cow and calf health. J. Dairy Sci. 102:5784-5810. https://doi.org/10.3168/jds.2018-15603.

Benetton, J. B., H. W. Neave, J. H. C. Costa, M. A. G. von Keyserlingk, and D. M. Weary. 2019. Automatic weaning based on individual solid feed intake: Effects on behavior and performance of dairy calves. J. Dairy Sci. 102:5475-5491. https://doi.org/10 $.3168 /$ jds.2018-15830.

Bertulat, S., C. Fischer-Tenhagen, and W. Heuwieser. 2015. A survey of drying-off practices on commercial dairy farms in northern 
Germany and a comparison to science-based recommendations. Vet. Rec. Open 2:e000068. https://doi.org/10.1136/vetreco-2014 -000068 .

Bleul, U. 2011. Risk factors and rates of perinatal and postnatal mortality in cattle in Switzerland. Livest. Sci. 135:257-264. https://doi .org/10.1016/j.livsci.2010.07.022.

Boulton, A. C., N. J. Kells, N. Cogger, C. B. Johnson, C. O'Connor, J. Webster, A. Palmer, and N. J. Beausoleil. 2020. Risk factors for bobby calf mortality across the New Zealand dairy supply chain. Prev. Vet. Med. 174:104836. https://doi.org/10.1016/j.prevetmed .2019.104836.

Brainard, J., L. Hooper, S. McFarlane, C. C. Hammer, P. R. Hunter, and K. Tyler. 2020. Systematic review of modifiable risk factors shows little evidential support for most current practices in Cryptosporidium management in bovine calves. Parasitol. Res. 119:3571-3584. https://doi.org/10.1007/s00436-020-06890-2.

Brickell, J. S., M. M. McGowan, D. U. Pfeiffer, and D. C. Wathes. 2009. Mortality in Holstein- Friesian calves and replacement heifers, in relation to body weight and IGF-I concentration, on 19 farms in England. Animal 3:1175-1182. https://doi.org/10.1017/ S175173110900456X.

Brickell, J. S., and D. C. Wathes. 2011. A descriptive study of the survival of Holstein-Friesian heifers through to third calving on English dairy farms. J. Dairy Sci. 94:1831-1838. https://doi.org/ 10.3168/jds.2010-3710.

Brown, A., F. Pearston, A. Wells, K. Matthews, M. Winters, and M. Coffey. 2020. Using genetics to improve dairy-bred \& dairy-beef carcases. Page in EAAP, 71st Annual Meeting of the European Federation of Animal Science, Porto, Portugal.

Brown, A. J., G. Scoley, N. O'Connell, J. Robertson, A. Browne, and S. Morrison. 2021. Pre-weaned calf rearing on northern Irish dairy farms: Part 1. A description of calf management and housing design. Animals 11:1954.

Bučková, K., R. Šárová, Á. Moravcsíková, and M. Špinka. 2021. The effect of pair housing on dairy calf health, performance, and behavior. J. Dairy Sci. 104:10282-10290. https://doi.org/10.3168/jds .2020-19968.

Camiloti, T. V., J. A. Fregonesi, M. A. G. von Keyserlingk, and D. M. Weary. 2012. Short communication: Effects of bedding quality on the lying behavior of dairy calves. J. Dairy Sci. 95:3380-3383. https://doi.org/10.3168/jds.2011-5187.

Clasen, J. B., A. Fogh, and M. Kargo. 2019. Differences between performance of $\mathrm{F} 1$ crossbreds and Holsteins at different production levels. J. Dairy Sci. 102:436-441. https://doi.org/10.3168/jds.2018 -14975 .

Cooke, J. S., Z. Cheng, N. E. Bourne, and D. C. Wathes. 2013. Association between growth rates, age at first calving and subsequent fertility, milk production and survival in Holstein-Friesian heifers. Open J. Anim. Sci. 3:1-12. https://doi.org/10.4236/ojas.2013 .31001 .

Costa, J. H. C., R. K. Meagher, M. A. G. von Keyserlingk, and D. M. Weary. 2015. Early pair housing increases solid feed intake and weight gains in dairy calves. J. Dairy Sci. 98:6381-6386. https:// doi.org/10.3168/jds.2015-9395.

Costa, J. H. C., M. A. G. von Keyserlingk, and D. M. Weary. 2016. Invited review: Effects of group housing of dairy calves on behavior, cognition, performance, and health. J. Dairy Sci. 99:2453-2467. https://doi.org/10.3168/jds.2015-10144.

Coughlin, S. S. 1990. Recall bias in epidemiologic studies. J. Clin. Epidemiol. 43:87-91. https://doi.org/10.1016/0895-4356(90)90060-3.

Creswell, J., and V. L. Clark. 2017. Designing and Conducting Mixed Methods Research. 3rd ed. SAGE Publications.

Curtis, G., C. McGregor Argo, D. Jones, and D. Grove-White. 2018. The impact of early life nutrition and housing on growth and reproduction in dairy cattle. PLoS One 13:e0191687. https://doi .org/10.1371/journal.pone.0191687.

Cuttance, E., and R. Laven. 2019a. Perinatal mortality risk factors in dairy calves. Vet. J. 253:105394. https://doi.org/10.1016/j.tvjl .2019 .105394 .
Cuttance, E., and R. Laven. 2019b. Estimation of perinatal mortality in dairy calves: A review. Vet. J. 252:105356. https://doi.org/10 $.1016 / j . t v j 1.2019 .105356$.

de Passillé, A. M., T. F. Borderas, and J. Rushen. 2011. Weaning age of calves fed a high milk allowance by automated feeders: Effects on feed, water, and energy intake, behavioral signs of hunger, and weight gains. J. Dairy Sci. 94:1401-1408. https://doi.org/10.3168/ jds.2010-3441.

De Paula Vieira, A., V. Guesdon, A. M. de Passillé, M. A. G. von Keyserlingk, and D. M. Weary. 2008. Behavioural indicators of hunger in dairy calves. Appl. Anim. Behav. Sci. 109:180-189. https://doi .org/10.1016/j.applanim.2007.03.006.

De Paula Vieira, A., M. A. G. von Keyserlingk, and D. M. Weary. 2010. Effects of pair versus single housing on performance and behavior of dairy calves before and after weaning from milk. J. Dairy Sci. 93:3079-3085. https://doi.org/10.3168/jds.2009-2516.

Duse, A., K. P. Waller, U. Emanuelson, H. E. Unnerstad, Y. Persson, and B. Bengtsson. 2013. Farming practices in Sweden related to feeding milk and colostrum from cows treated with antimicrobials to dairy calves. Acta Vet. Scand. 55:49. https://doi.org/10.1186/ 1751-0147-55-49.

Duthie, C.-A., J. M. Bowen, D. J. Bell, G. A. Miller, C. Mason, and M. J. Haskell. 2021. Feeding behaviour and activity as early indicators of disease in pre-weaned dairy calves. Animal 15:100150.

Ellingsen, K., C. M. Mejdell, B. Hansen, A. M. Grøndahl, B. I. F. Henriksen, and M. Vaarst. 2012. Veterinarians' and agricultural advisors' perception of calf health and welfare in organic dairy production in Norway. Org. Agric. 2:67-77. https://doi.org/10.1007/ s13165-012-0025-8.

Ellingsen, K., C. M. Mejdell, N. Ottesen, S. Larsen, and A. M. Grøndahl. 2016. The effect of large milk meals on digestive physiology and behaviour in dairy calves. Physiol. Behav. 154:169-174. https: //doi.org/10.1016/j.physbeh.2015.11.025.

Esslemont, R. J., and M. A. Kossaibati. 1997. Culling in 50 dairy herds in England. Vet. Rec. 140:36-39. https://doi.org/10.1136/ vr.140.2.36.

Fisher, M., R. Wild, K. O'Grady, M. Guigou, T. Diesch, J. Jamieson, L. Ward, and N. Cross. 2017. The welfare of bobby calves sent for slaughter: A synopsis of the science literature within the context of New Zealand's export system and the problems and gaps in it. Pages 149-153 in N.Z. Soc. Ani. Prod.

Fossaert, C., D. Pichon, G. Le Milet, M. Douguet, J. Bertron, and S. Brouard. 2020. In France, a new dairy calf to beef production for the out of home consumers. Page in EAAP, 71st Annual Meeting of the European Federation of Animal Science, Porto, Portugal. EAAP.

Friedman, D. B., C. P. Kanwat, M. L. Headrick, N. J. Patterson, J. C. Neely, and L. U. Smith. 2007. Importance of prudent antibiotic use on dairy farms in South Carolina: A pilot project on farmers' knowledge, attitudes and practices. Zoonoses Public Health 54:366-375. https://doi.org/10.1111/j.1863-2378.2007.01077.x.

Geiger, A. J., C. L. M. Parsons, R. E. James, and R. M. Akers. 2016. Growth, intake, and health of Holstein heifer calves fed an enhanced preweaning diet with or without postweaning exogenous estrogen. J. Dairy Sci. 99:3995-4004. https://doi.org/10.3168/jds .2015-10405.

Ghaffari, M. H., and A. F. Kertz. 2021. Review: Effects of different forms of calf starters on feed intake and growth rate: A systematic review and Bayesian meta-analysis of studies from 1938 to 2021. Appl. Anim. Sci. 37:273-293. https://doi.org/10.15232/aas.2021 $-02150$.

Größbacher, V., A. Lawrence, C. Winckler, and M. Špinka. 2020. Negative play contagion in calves. Sci. Rep. 10:21699.

Habing, G., C. Djordjevic, G. M. Schuenemann, and J. Lakritz. 2016. Understanding antimicrobial stewardship: Disease severity treatment thresholds and antimicrobial alternatives among organic and conventional calf producers. Prev. Vet. Med. 130:77-85. https:// doi.org/10.1016/j.prevetmed.2016.06.004. 
Hötzel, M. J., C. S. Cardoso, A. Roslindo, and M. A. G. von Keyserlingk. 2017. Citizens' views on the practices of zero-grazing and cow-calf separation in the dairy industry: Does providing information increase acceptability? J. Dairy Sci. 100:4150-4160. https:// doi.org/10.3168/jds.2016-11933.

Hyde, R. M., M. J. Green, C. Hudson, and P. M. Down. 2021. Factors associated with daily weight gain in preweaned calves on dairy farms. Prev. Vet. Med. 190:105320. https://doi.org/10.1016/j .prevetmed.2021.105320.

Hyde, R. M., M. J. Green, V. E. Sherwin, C. Hudson, J. Gibbons, T. Forshaw, M. Vickers, and P. M. Down. 2020. Quantitative analysis of calf mortality in Great Britain. J. Dairy Sci. 103:2615-2623. https://doi.org/10.3168/jds.2019-17383.

Jansen, J., and T. J. G. M. Lam. 2012. The role of communication in improving udder health. Vet. Clin. North Am. Food Anim. Pract. 28:363-379. https://doi.org/10.1016/j.cvfa.2012.03.003.

Jansen, J., R. J. Renes, and T. J. G. M. Lam. 2010a. Evaluation of two communication strategies to improve udder health management. J. Dairy Sci. 93:604-612. https://doi.org/10.3168/jds.2009-2531.

Jansen, J., C. D. M. Steuten, R. J. Renes, N. Aarts, and T. J. G. M. Lam. 2010b. Debunking the myth of the hard-to-reach farmer: Effective communication on udder health. J. Dairy Sci. 93:12961306. https://doi.org/10.3168/jds.2009-2794.

Johnsen, J. F., I. H. Holmøy, C. M. Mejdell, K. Ellingsen-Dalskau, O. Østerås, A. Døsen, E. Skjerve, and A. Nødtvedt. 2021. A crosssectional study of associations between herd-level calf mortality rates, compliance with legislation on calf welfare, and milk feeding management in Norwegian dairy herds. J. Dairy Sci. 104:839-848. https://doi.org/10.3168/jds.2020-18865.

Johnson, K. F., N. Chancellor, C. C. Burn, and D. C. Wathes. 2017. Prospective cohort study to assess rates of contagious disease in pre-weaned UK dairy heifers: Management practices, passive transfer of immunity and associated calf health. Vet. Rec. Open 4:e000226.

Jorgensen, M. W., A. Adams-Progar, A. M. de Passillé, J. Rushen, S. M. Godden, H. Chester-Jones, and M. I. Endres. 2017. Factors associated with dairy calf health in automated feeding systems in the Upper Midwest United States. J. Dairy Sci. 100:5675-5686. https: //doi.org/10.3168/jds.2016-12501.

Keeling, L. J., and J. F. Hurnik. 1996. Social facilitation and synchronization of eating between familiar and unfamiliar newly weaned piglets. Acta Agric. Scand. A Anim. Sci. 46:54-60. https://doi .org/10.1080/09064709609410924.

Kelly, T. G., V. A. Dodd, and D. J. Ruane. 1986. Ventilation and air flow patterns in climatic calf houses. J. Agric. Eng. Res. 33:187203. https://doi.org/10.1016/S0021-8634(86)80049-X.

Knauer, W. A., S. M. Godden, A. Dietrich, D. M. Hawkins, and R. E. James. 2018. Evaluation of applying statistical process control techniques to daily average feeding behaviors to detect disease in automatically fed group-housed preweaned dairy calves. J. Dairy Sci. 101:8135-8145. https://doi.org/10.3168/jds.2017-13947.

Lago, A., S. M. McGuirk, T. B. Bennett, N. B. Cook, and K. V. Nordlund. 2006. Calf respiratory disease and pen microenvironments in naturally ventilated calf barns in winter. J. Dairy Sci. 89:40144025. https://doi.org/10.3168/jds.S0022-0302(06)72445-6.

Li, J. H., M. H. Yousif, Z. Q. Li, Z. H. Wu, S. L. Li, H. J. Yang, Y. J. Wang, and Z. J. Cao. 2019. Effects of antibiotic residues in milk on growth, ruminal fermentation, and microbial community of preweaning dairy calves. J. Dairy Sci. 102:2298-2307. https:// doi.org/10.3168/jds.2018-15506.

Louie, A. P., J. D. Rowe, W. J. Love, T. W. Lehenbauer, and S. S. Aly. 2018. Effect of the environment on the risk of respiratory disease in preweaning dairy calves during summer months. J. Dairy Sci. 101:10230-10247. https://doi.org/10.3168/jds.2017-13716.

MacPherson, J., S. J. Meale, K. Macmillan, J. Haisan, C. J. Bench, M. Oba, and M. A. Steele. 2019. Effects of feeding frequency of an elevated plane of milk replacer and calf age on behavior, and glucose and insulin kinetics in male Holstein calves. Animal 13:1385-1393. https://doi.org/10.1017/S175173111800294X.

Mahendran, S. 2021. Survey. Figshare. Online resource. https://doi .org/https://doi.org/10.6084/m9.figshare.16856518.
Mahendran, S. A., D. C. Wathes, R. E. Booth, and N. Blackie. 2021. The health and behavioural effects of individual versus pair housing of calves at different ages on a UK commercial dairy farm. Animals (Basel) 11:612. https://doi.org/10.3390/ani11030612.

Marcé, C., R. Guatteo, N. Bareille, and C. Fourichon. 2010. Dairy calf housing systems across Europe and risk for calf infectious diseases. Animal 4:1588-1596. https://doi.org/10.1017/S1751731110000650.

Maynou, G., A. Bach, and M. Terré. 2017. Feeding of waste milk to Holstein calves affects antimicrobial resistance of Escherichia coli and Pasteurella multocida isolated from fecal and nasal swabs. J. Dairy Sci. 100:2682-2694. https://doi.org/10.3168/jds.2016-11891.

Meagher, R. K., A. Beaver, D. M. Weary, and M. A. G. von Keyserlingk. 2019. Invited review: A systematic review of the effects of prolonged cow-calf contact on behavior, welfare, and productivity. J. Dairy Sci. 102:5765-5783. https://doi.org/10.3168/jds.2018 $-16021$.

Medrano-Galarza, C., S. J. LeBlanc, T. J. DeVries, A. Jones-Bitton, J. Rushen, A. Marie de Passillé, and D. B. Haley. 2017. A survey of dairy calf management practices among farms using manual and automated milk feeding systems in Canada. J. Dairy Sci 100:6872-6884. https://doi.org/10.3168/jds.2016-12273.

Mee, J. F. 2008. Newborn dairy calf management. Vet. Clin. North Am. Food Anim. Pract. 24:1-17. https://doi.org/10.1016/j.cvfa 2007.10.002.

Mee, J. F., D. P. Berry, and A. R. Cromie. 2008. Prevalence of, and risk factors associated with, perinatal calf mortality in pasturebased Holstein-Friesian cows. Animal 2:613-620. https://doi.org/ 10.1017/S1751731108001699.

Moya, S., K. W. R. Chan, S. Hinchliffe, H. Buller, J. Espluga, B. Benavides, F. J. Diéguez, E. Yus, G. Ciaravino, J. Casal, F. Tirado, and A. Allepuz. 2021. Influence on the implementation of biosecurity measures in dairy cattle farms: Communication between veterinarians and dairy farmers. Prev. Vet. Med. 190:105329. https://doi .org/10.1016/j.prevetmed.2021.105329.

Nordlund, K. V., and C. E. Halbach. 2019. Calf barn design to optimize health and ease of management. Vet Clin. North Am. Food Anim. Pract. 35:29-45.

Raboisson, D., F. Delor, E. Cahuzac, C. Gendre, P. Sans, and G. Allaire. 2013. Perinatal, neonatal, and rearing period mortality of dairy calves and replacement heifers in France. J. Dairy Sci. 96:2913-2924. https://doi.org/10.3168/jds.2012-6010.

Ritter, C., J. Jansen, S. Roche, D. F. Kelton, C. L. Adams, K. Orsel, R. J. Erskine, G. Benedictus, T. J. G. M. Lam, and H. W. Barkema. 2017. Invited review: Determinants of farmers' adoption of management-based strategies for infectious disease prevention and control. J. Dairy Sci. 100:3329-3347. https://doi.org/10.3168/ jds.2016-11977.

Robinson, P. A. 2020. "They've got to be testing and doing something about it": Farmer and veterinarian views on drivers for Johne's disease control in dairy herds in England. Prev. Vet. Med. 182:105094. https://doi.org/10.1016/j.prevetmed.2020.105094.

Rose, D. C., C. Keating, E. Vrain, and C. Morris. 2018. Beyond individuals: Toward a "distributed" approach to farmer decisionmaking behavior. Food Energy Secur. 7:e00155. https://doi.org/ $10.1002 /$ fes3.155.

Rosenberger, K., J. H. C. Costa, H. W. Neave, M. A. G. von Keyserlingk, and D. M. Weary. 2017. The effect of milk allowance on behavior and weight gains in dairy calves. J. Dairy Sci. 100:504-512. https://doi.org/10.3168/jds.2016-11195.

Roth, B. A., N. M. Keil, L. Gygax, and E. Hillmann. 2009. Influence of weaning method on health status and rumen development in dairy calves. J. Dairy Sci. 92:645-656. https://doi.org/10.3168/ jds.2008-1153.

Rushen, J., and A. M. de Passillé. 1995. The motivation of non-nutritive sucking in calves, Bos taurus. Anim. Behav. 49:1503-1510. https://doi.org/10.1016/0003-3472(95)90071-3.

Rutherford, N. H., A. W. Gordon, G. Arnott, and F. O. Lively. 2019. The effect of calf jackets on the health, performance, and skin temperature of dairy origin beef calves. Transl. Anim. Sci. 4:316-323. https://doi.org/10.1093/tas/txz172. 
Salter, R. S., K. J. Reuscher, and J. M. C. Van Os. 2021. Milk- and starter-feeding strategies to reduce cross sucking in pair-housed calves in outdoor hutches. J. Dairy Sci. 104:6096-6112. https://doi .org/10.3168/jds.2020-19380.

Santman-Berends, I. M. G. A., G. H. Nijhoving, L. van Wuijckhuise, J. Muskens, I. Bos, and G. van Schaik. 2021. Evaluation of the association between the introduction of data-driven tools to support calf rearing and reduced calf mortality in dairy herds in the Netherlands. Prev. Vet. Med. 191:105344. https://doi.org/10.1016/j .prevetmed.2021.105344.

Scoley, G., A. Gordon, and S. J. Morrison. 2019. The effect of calf jacket usage on performance, behaviour and physiological responses of group-housed dairy calves. Animal 13:2876-2884. https://doi.org/ 10.1017/S1751731119001071.

Shivley, C. B., J. E. Lombard, N. J. Urie, D. M. Weary, and M. A. G. von Keyserlingk. 2019. Management of preweaned bull calves on dairy operations in the United States. J. Dairy Sci. 102:4489-4497. https://doi.org/10.3168/jds.2018-15100.

Sinnott, A. M., E. Kennedy, and E. A. M. Bokkers. 2021. The effects of manual and automated milk feeding methods on group-housed calf health, behaviour, growth and labour. Livest. Sci. 244:104343. https://doi.org/10.1016/j.livsci.2020.104343.

Sischo, W. M., D. A. Moore, R. Pereira, L. Warnick, D. L. Moore, J. Vanegas, S. Kurtz, K. Heaton, D. Kinder, J. Siler, and M. A. Davis. 2019. Calf care personnel on dairy farms and their educational opportunities. J. Dairy Sci. 102:3501-3511. https://doi.org/ $10.3168 /$ jds.2018-15401.

Spinka, M., R. C. Newberry, and M. Bekoff. 2001. Mammalian play: Training for the unexpected. Q. Rev. Biol. 76:141-168. https://doi . org $/ 10.1086 / 393866$.

Sumner, C. L., and M. A. G. von Keyserlingk. 2018. Canadian dairy cattle veterinarian perspectives on calf welfare. J. Dairy Sci. 101:10303-10316. https://doi.org/10.3168/jds.2018-14859.

Tapkı, I., A. Şahin, and A. G. Önal. 2006. Effect of space allowance on behaviour of newborn milk-fed dairy calves. Appl. Anim. Behav. Sci. 99:12-20. https://doi.org/10.1016/j.applanim.2005.09.006. van Dijk, J., S. J. Eagle, A. V. Gillespie, R. F. Smith, A. N. Holman, and H. J. Williams. 2015. Visual weight estimation and the risk of underdosing dairy cattle. Vet. Rec. 177:75. https://doi.org/10 $.1136 /$ vr.102955.

Velasova, M., A. Damaso, B. C. Prakashbabu, J. Gibbons, N. Wheelhouse, D. Longbottom, S. Van Winden, M. Green, and J. Guitian. 2017. Herd-level prevalence of selected endemic infectious diseases of dairy cows in Great Britain. J. Dairy Sci. 100:9215-9233. https: //doi.org/10.3168/jds.2016-11863.

Ventura, B. A., M. A. G. von Keyserlingk, C. A. Schuppli, and D. M. Weary. 2013. Views on contentious practices in dairy farming: The case of early cow-calf separation. J. Dairy Sci. 96:6105-6116. https: //doi.org/10.3168/jds.2012-6040.

Wathes, C. M., K. Howard, C. D. R. Jones, and A. J. F. Webster. 1984. The balance of airborne bacteria in calf houses. J. Agric. Eng. Res. 30:81-90. https://doi.org/10.1016/S0021-8634(84)80009 -8 .

Wilms, J., H. Berends, and J. Martín-Tereso. 2019. Hypertonic milk replacers increase gastrointestinal permeability in healthy dairy calves. J. Dairy Sci. 102:1237-1246. https://doi.org/10.3168/jds .2018-15265.

Windsor, P. A., and R. J. Whittington. 2010. Evidence for age susceptibility of cattle to Johne's disease. Vet. J. 184:37-44. https://doi .org/10.1016/j.tvjl.2009.01.007.

Wood, S., K. K. Reyher, and D. C. Barrett. 2015. Comparison of visual assessment and heart girth tape measurement for estimating the weight of cattle in clinical practice. Vet. J. 203:337-338. https: //doi.org/10.1016/j.tvjl.2014.12.034.

\section{ORCIDS}

S. A. Mahendran (ㄴ) https://orcid.org/0000-0003-2170-7112

D. C. Wathes $\odot$ https://orcid.org/0000-0002-8206-6091

N. Blackie @ https://orcid.org/0000-0002-4247-4015 